\title{
Discrimination Against Urban Women: A Case Study Of Karachi
}

\author{
Fateh Muhammad Burfat \\ Naima Saeed \\ \& \\ Ghulam Muhammad Burfat \\ Department of Sociology \\ University of Karachi
}

\begin{abstract}
Gender inequality exists in Pakistan as a phenomenon that does not allow women equality of opportunity in the public and private sphere and also keeps women in very subjugated roles within the public and in private relationships. These factors can affect women's access to education, employment, to career advancement and to their possibilities of holding positions of political power and roles of social and cultural esteem. Although gender equality may have progressed somewhat in the modern world but it is still an issue of great urgency in other parts of the world as well as in Pakistan, that is the focus of this study. This research investigates the types and consequences of gender discrimination that exist. The findings from the study suggest that the urban women in the sample of the present study still struggle for gender equality with men in Pakistan. The results show that in a number of areas, in both family and public life, they are still seen by many as second class citizens; and see their own autonomy and opportunities as limited. The social class of urban women in Pakistan is strongly related to their opportunities. Urban women from upper and middle class backgrounds enjoy more autonomy and equality in their lives as compare to women from poor backgrounds. These findings tend to support historical data in relation to women in Pakistan.
\end{abstract}

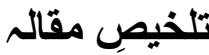

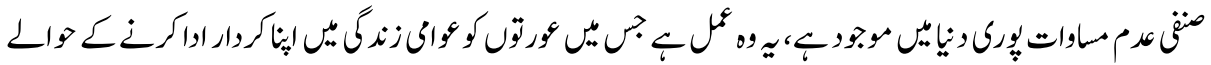

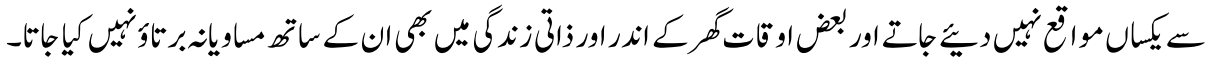

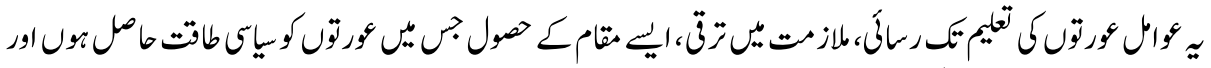

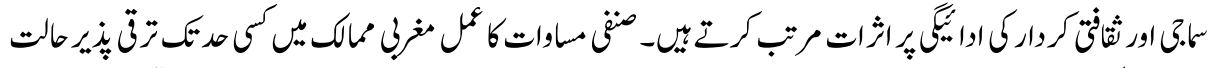

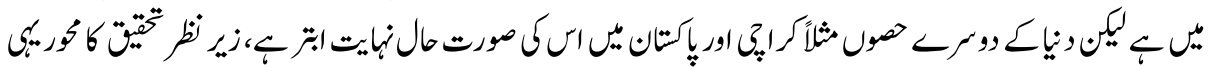

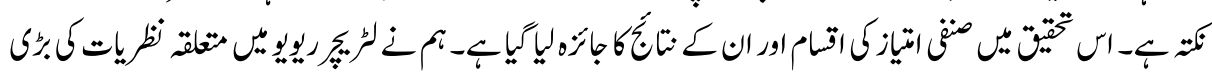

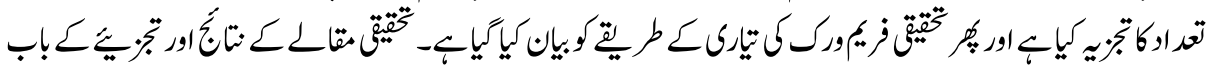

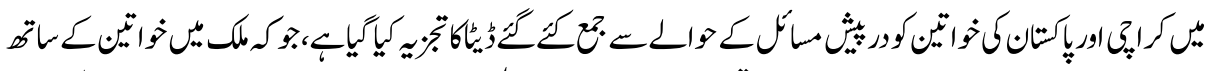

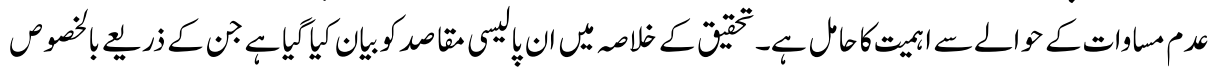

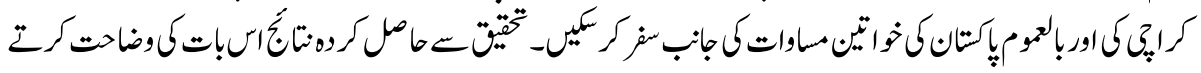




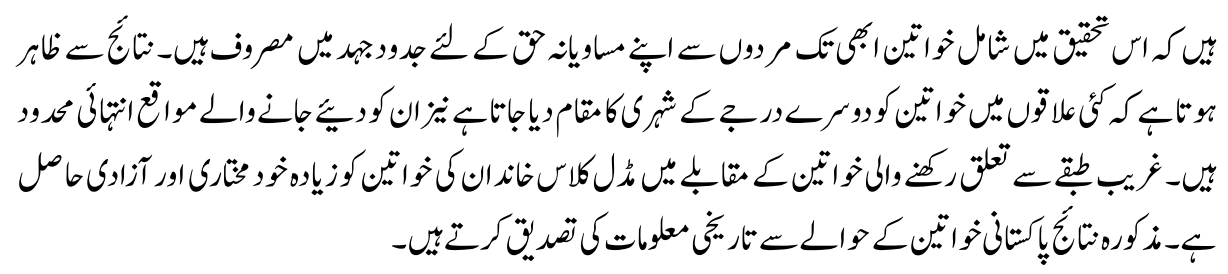

Keywords: Equality, discrimination, gender, sex, urban women, feminism, poverty, health, education, income gap, family structure, survey research.

\section{Introduction}

Social justice and human rights are the fundamental outcomes of equality which is the origin of a democratic society. It is a matter of fact that women are the victims of inequalities in almost every aspect of life in the public and private spheres, regardless of the geographical location they are living in pathological conditions. The worst faces of this deep rooted discrimination against women can be witnessed in homes, the workplace and in overall society as well. However, in what manners women are discriminated against may vary from country to country, society to society and culture to culture. Stereotypes, tradition and cultural mind set, and some religious practices and beliefs are the reasons of unfavorable circumstances to women. (Vienna Declaration and Program of Action, 1993)

The term discrimination is derived from the Latin word 'discriminatio' which literally means to keep separate, to make distinction or to judge different members of society with biases. From a sociological perspective, discrimination is comprised of highly complex social process. Alex Thio explains that "discrimination is an unfavorable action against individuals that is taken because they are members of a certain category"(Thio, 1996: 266).According to J.M.Henslin (1992:330) discrimination is "an act of unfair treatment directed against an individual or a group."

Discrimination is opposed to the concept of equality. In general equality means treating everyone in the same manner, but in practice equality is far more than that. Injustice arises when people are treated unequally in equal situations. These situational imbalances are the main hindrances in implementing true equality and hence they are required to be resolved. This broader view of equality has become a leading principle and ultimate objective in the struggle for recognition and acceptance of women's rights. (World Conference on Human Rights, 1993) 


\section{General Situation of Women in Pakistan}

The Sustainable Development Policy Institute (SDPI) has undertaken a "Country Gender Profile study," in partnership with Japan International Cooperation Agency (JICA).The study (2008) was focused on :

- The overall status of women and men, from a gender equality perspective,

- Gaps between gender policies and their implementation,

- Chronic and emerging gender issues from a social change and development perspective.

The focused period was from 1999 to 2007. The underlying principles were to be analyzed in relation to:

- The policy environment,

- Socio cultural context,

- Customary practices,

- Changing norms and traditions,

- And human behaviors impacting on women and men's socio-economic development in Pakistan.

According to a Global Gender Gap (GGG) report. The top ten worst countries, where the rights of women are offended against, are: Yemen, Chad, Pakistan, Nepal, Saudi Arabia, Benin, Morocco, Turkey, Egypt and Oman. And nine out of these ten countries are Muslim countries. A careful research process is needed to focus on this problem. (Hausmann and Zahidi, 2008)

The GGG report in (2008) collected data from a total of 128 countries to develop a comprehensive, scientific index by GGG. The GGG index is comprised of four different indicators. These are:

- Economic participation

- Educational attainment

- Political empowerment

- Health and Survival

Under economic participation, five of the worst-offenders of women rights are: Yemen, Saudi Arabia, Pakistan, Oman and Bahrain. Under educational attainment, the worstoffenders are: Chad, Yemen, Benin and Pakistan, the worst countries for women are: Saudi Arabia, Yemen, Kuwait, Qatar, Egypt and Iran. Under economic participation, Pakistan is ranked126 out of 128 countries. For educational attainment, Pakistan ranks 123 out of 128 . Under Health, it is at 121 of 128 countries. And under political empowerment, Pakistan is at 43 out of a possible 128 countries. The report clearly presents a black state of social indicators in Pakistan. (Global Gender Gap, 2008) 


\section{Objectives of the Study}

1. To analyze the relationship between monthly family income of women in Karachi, and their opinions about participation in productive activities outside the home.

2. To explore the relationship between the working status of women in Karachi, and their participation in important decision making in the family.

3. To find out the relationship between educational status of women in Karachi, and their consultation about marriage.

4. To investigate the relationship between educational status of women in Karachi, and their opinion about gender equality.

\section{Hypothesis of the Study}

Monthly family income of women is likely to be related to participate in productive activities outside the home.

The working status of women is likely to be related participation in important decision making in the family Educational status of women is likely to be related their consultation about marriage. Educational status of women is likely to be related their opinion about gender equality.

\section{Literature Review}

There is considerable literature concerning discrimination against women worldwide. The nature of discrimination, however, varies in different cultures and countries. In the developing countries, discrimination is evident because of socio-economic conditions of women and their rights, type of marriage and physical mobility, number of children and women's health, educational status of women and their equality. The aim of theoretical background and literature review is to guide researchers about their research projects and provide them information in this regard. The published researches in the given field, already done by researches and scholars are explained through it. (Sekaran, 1992:37).

Holmes,(2007) examines common sense ideas about sex differences, and defined terms such as sex, gender, patriarchy and social construction. Gender was explained as a natural phenomenon. Social environment was taken as a key factor in shaping gender. It was mentioned that the roles of women and men in some cultures are similar, not opposite. The theme of how gender operated within social life was explained. In this process, attention was drawn to socialization theories, and specially how symbolic interactionism sees gender. In gender theorizing, major debates around the issues of equality versus difference, and key feminist approaches were emphasized. Another related book on the topic S.M. Jaffri, (2004) observes conditions of Muslim women in 
Muslim and non-Muslim societies has been made. The debate regarding the status of men and women in Islam, and the western concept of 'equality' was highlighted. It was noted that 'illiteracy', is widespread in most of the Muslim countries. In his book, he analyzes a case study of women's status in Karachi. It is concluded that the Islamization programme in the 1980's affected women both directly and indirectly and was used as a political tool to legitimize government control over society. The chapters of this book show how religion has been used to discriminate against women, and the ways in which urban women resisted this. The chapter also describes women's domestic role, women in urban settings, conservative Islamic views regarding women, and women resistance. This study has very carefully presented the situation of the women of Karachi, Pakistan and it shows a clear discrimination with them (her) in most of the field of life.

Jo Freeman, (1995) studies different characteristics of feminist standpoint. It covers different aspects of feminist perspective. It noted that women are seen as a group. A women's right to herself is the most fundamental issue. The practices as rape, wife assault, the sexual abuse of children, and sexual harassment are different forms of sexual terrorism. They are meant to frighten control and dominate females by males. Sexual harassment has been taken as crime only recently. It is now treated an illegal type of sex discrimination. It was highlighted that a women's body has been used and misused to achieve political ends. The family was discussed both the historical and anthropological contexts. It was pointed out that the sexual division of labour is anachronistic. The true strength of this book exists not in its facts but in its notions, and in the comprehensive orientation provided in a feminist perspective. The feminist perspective can best be understood as compare to its traditional interpretations. The feminist perspective investigated for the similarities between two genders and it was concluded that women and men both have equal potential for their development. Differences occur in the realization of that potential therefore, results must be drawn from externally imposed restraints and also from the influence of social institutions and values. The feminist view holds that as long as society enforces sex roles and social consequences for those who diverge from them, no meaningful choice exists for members of either sex. Such roles and restraints are incisively examined and challenged in this book. The author concludes with a section on feminism as the historical and contemporary challenge to that status.

Fawcett et.al (1984) examine the situation of urban women in Asia. It is the first comprehensive examination of female migration and the situation of urban women in Asia. Based upon the studies and insights of sociologists, anthropologists, economists, geographers, and demographers, the book has documented the striking changes that are in progress and analyzed in depth the causes and consequences of emerging patterns of female mobility. Special attention is given to examine public policies and special responsibilities that burdened up women when it comes to working mothers or heads of household. In the past decade the migration of women from village to city has increased 
dramatically, and many of these new migrants are young single women seeking jobs. In several Asian countries women have to go through with new problems that are particularly associated with living in cities, and the prospect of fundamental changes in status of women fluctuates upward or downward. Changes in the migration patterns of women are considered as the major factor in economic development and social change, and it provides a new insight about the modernization process and suggests that female mobility is essential as far as bright Asian future is concerned. The migration of women especially to large cities is both a reflection of ongoing social change and an indication of future changes that are just about to come. The proportion of women in urban ward migration streams is increasing, and the number of women migrants to major urban areas has outnumbered men in many Asian countries. Such changes are occurring in constrained, such as Korea and Malaysia, as well as in more open social systems, such as Thailand and the Philippines. There is also important difference within countries where very little change is evident, and Pakistan is a notable example in this regard. In addressing the migration of women in Asia and their urban adaptation, the preceding chapters of the research study have related this spatial mobility to prevailing cultural norms and changing socio-economic conditions. The theoretical and empirical perspectives offered by these chapters are important contributions to consider of the role of women in the migration process in Asia. In end it is necessary to mention that the average migrant woman in Pakistan does not seem to represent the poorest and most illiterate section of the population.

\section{Methodology}

The present study is an exploratory research. The universe of the present study was Karachi Division. The data from each district was collected keeping in view the presence of the female population in each district. The probability sampling techniques was used for obtaining representative samples. Keeping in view the universe, a sample of 300 respondents was decided upon, to be selected in a quota technique. The survey method was used in the present study. The Data was collected using a structured interview schedule. The interview schedule contained on 10 sections and 99 questions. The method of interview involved reading and explaining questions to the respondents and recording their answers on the sheets. The process of coding was used to transfer raw data into SPSS format. The data analysis is done on computer, SPSS xvi was used to analysis the data. In the present study chi-square test was applied to verify the relationship between two variables and to support either the experimental or null hypotheses. 


\section{Results of Hypotheses}

Table 1

Table for Hypothesis 1

\begin{tabular}{|l|c|c|c|c|c|c|}
\hline \multicolumn{1}{|c|}{$\begin{array}{c}\text { Monthly } \\
\text { Family Income }\end{array}$} & \multicolumn{4}{|c|}{$\begin{array}{c}\text { Women Should Participate In Productive } \\
\text { Activities Outside The Home }\end{array}$} & \multirow{2}{*}{ Total } \\
\cline { 1 - 6 } $\begin{array}{l}\text { Monthly family } \\
\text { income }\end{array}$ & $\begin{array}{l}\text { Strongly } \\
\text { Agree }\end{array}$ & Agree & $\begin{array}{l}\text { Can't } \\
\text { Say }\end{array}$ & Disagree & $\begin{array}{l}\text { Strongly } \\
\text { Disagree }\end{array}$ & \\
\hline Low $(<15000)$ & 8 & 30 & 6 & 8 & 6 & 58 \\
\hline $\begin{array}{l}\text { Average (15000 } \\
-45000)\end{array}$ & 30 & 122 & 8 & 23 & 18 & 201 \\
\hline High $(>45000)$ & 12 & 8 & 5 & 10 & 6 & 41 \\
\hline Total & $\mathbf{5 0}$ & $\mathbf{1 6 0}$ & $\mathbf{1 9}$ & $\mathbf{4 1}$ & $\mathbf{3 0}$ & $\mathbf{3 0 0}$ \\
\hline
\end{tabular}

To test the hypothesis, Pearson's chi-square contingency test was applied at 0.05 degree of significance. The following results were obtained:

\begin{tabular}{|c|c|c|c|}
\hline \multicolumn{4}{|l|}{ Chi-Square Tests } \\
\hline & Value & Df & Asymp. Sig. (2-sided) \\
\hline Pearson Chi-Square & $33.935^{\mathrm{a}}$ & 8 & .245 \\
\hline Likelihood Ratio & 25.072 & 8 & .199 \\
\hline Linear-by-Linear Association & 6.104 & 1 & .013 \\
\hline $\mathrm{N}$ of Valid Cases & 300 & & \\
\hline
\end{tabular}

The calculated value of chi-square is 33.935 , which is greater than the table value of 15.5073 at 0.05 level of significance and 8 degree of freedom. The null hypothesis 1 is rejected. Hence, the opinion about women's participation in productive activities outside the home depends on the family's monthly income. The phi-coefficient value of 0.336 indicates a positive relationship between the variables.

Table 2

Table for Hypothesis 2

\begin{tabular}{|c|c|c|c|c|c|c|c|}
\hline \multirow{2}{*}{$\begin{array}{c}\text { Working } \\
\text { Status Of } \\
\text { Women }\end{array}$} & \multicolumn{6}{|c|}{$\begin{array}{l}\text { Women's Participation In Important Decision Making } \\
\text { In Their Family. }\end{array}$} & \multirow{2}{*}{ Total } \\
\hline & Father & Mother & Yourself & Husband & Both & Other & \\
\hline Working & 17 & 6 & 15 & 68 & 24 & 5 & 135 \\
\hline Non-working & 30 & 8 & 18 & 52 & 50 & 7 & 165 \\
\hline Total & 47 & 14 & 33 & 120 & 74 & 12 & 300 \\
\hline
\end{tabular}


To test the hypothesis, Pearson's chi-square contingency test was applied at 0.05 degree of significance. The following results were obtained:

\begin{tabular}{|c|c|c|c|}
\hline \multicolumn{4}{|l|}{ Chi-Square Tests } \\
\hline & Value & df & Asymp. Sig. (2-sided) \\
\hline Pearson Chi-Square & $38.707^{\mathrm{a}}$ & 5 & .000 \\
\hline Likelihood Ratio & 39.959 & 5 & .000 \\
\hline Linear-by-Linear Association & 11.356 & 1 & .001 \\
\hline $\mathrm{N}$ of Valid Cases & 300 & & \\
\hline
\end{tabular}

The calculated value of chi-square is 38.707 , which is greater than the table value of chisquare 9.4877 at 0.05 level of significance and 5 degree of freedom. The null hypothesis 2 is rejected. Therefore, the decision-making roles in a family depend on the respondents' working status. The phi-coefficient value of 0.359 indicates a positive relationship between the variables.

Table 3

Table for Hypothesis 3

\begin{tabular}{|l|c|c|c|}
\hline \multicolumn{1}{|c|}{$\begin{array}{c}\text { Educational Status of } \\
\text { Women }\end{array}$} & \multicolumn{2}{c|}{ Consultation About Marriage } & Total \\
\hline Low & Yes & No & \\
\hline Average & 27 & 75 & 102 \\
\hline High & 57 & 13 & 70 \\
\hline Total & 63 & 8 & 71 \\
\hline
\end{tabular}

To test the hypothesis, Pearson's chi-square contingency test was applied at 0.05 degree of significance. The following results were obtained:

\begin{tabular}{|l|c|c|c|}
\hline \multicolumn{4}{|l|}{ Chi-Square Tests } \\
\hline & Value & df & Asymp. Sig. (2-sided) \\
\hline Pearson Chi-Square & $15.955^{\text {a }}$ & 2 & .014 \\
\hline Likelihood Ratio & 17.680 & 2 & .007 \\
\hline Linear-by-Linear Association & 11.266 & 1 & .001 \\
\hline N of Valid Cases & 190 & & \\
\hline
\end{tabular}

a. 6 cells $(42.9 \%)$ have expected count less than 5 . The minimum expected count is .52 . 
The calculated value of chi-square is 15.955 , which is greater than the table value of chi-square 5.99147 at 0.05 level of significance and 2 degree of freedom. The null hypothesis 6 is rejected. Therefore, the consultation before marriage depends on the respondents' educational status. The phi-coefficient value of 0.290 indicates a insignificant positive relationship between variables.

Table 4

Table for Hypothesis 4

\begin{tabular}{|c|c|c|c|c|c|c|}
\hline \multirow{2}{*}{$\begin{array}{c}\text { Educational } \\
\text { Status Of } \\
\text { Women }\end{array}$} & \multicolumn{5}{|c|}{ Opinion Of Women About Gender Equality } & \multirow[t]{2}{*}{ Total } \\
\hline & $\begin{array}{c}\text { Strongly } \\
\text { Agree }\end{array}$ & Agree & $\begin{array}{c}\text { Can't } \\
\text { Say }\end{array}$ & Disagree & $\begin{array}{l}\text { Strongly } \\
\text { Disagree }\end{array}$ & \\
\hline $\begin{array}{l}\text { Low (Below } \\
\text { Matriculation) }\end{array}$ & 50 & 11 & 5 & 52 & 16 & 134 \\
\hline $\begin{array}{l}\text { Medium } \\
\text { (Matriculation) }\end{array}$ & 25 & 15 & 7 & 22 & 10 & 79 \\
\hline $\begin{array}{l}\text { High } \\
\text { (Intermediate } \\
\text { \& Above) }\end{array}$ & 33 & 13 & 6 & 20 & 15 & 87 \\
\hline Total & 108 & 39 & 18 & 94 & 41 & 300 \\
\hline
\end{tabular}

To test the hypothesis, Pearson's chi-square contingency test was applied at 0.05 degree of significance. The following results were obtained:

\begin{tabular}{|l|c|c|c|}
\hline \multicolumn{4}{|l|}{ Chi-Square Tests } \\
\hline & Value & df & Asymp. Sig. (2-sided) \\
\hline Pearson Chi-Square & $34.713^{\text {a }}$ & 8 & .178 \\
\hline Likelihood Ratio & 39.130 & 8 & .079 \\
\hline Linear-by-Linear Association & 21.847 & 1 & .000 \\
\hline N of Valid Cases & 244 & & \\
\hline
\end{tabular}

a. 28 cells $(70.0 \%)$ have expected count less than 5 . The minimum expected count is .05 .

The calculated value of chi-square is 34.713 , which is greater than the table value of chisquare 15.5073 at 0.05 level of significance and 8 degree of freedom. The null hypothesis 7 is rejected. Therefore, the opinion about gender equality depends on the respondents' educational status. The phi-coefficient value of 0.377 indicates a positive relationship between variables.

\section{Conclusions}

The present research was planned and conducted to find out facts about discrimination against urban women in Pakistan with special reference to Karachi, and urban women 
from Karachi, were included in the sample of this study. The data acquired have been analysed and the following conclusions have been drawn from the statistical analysis of hypotheses.

1. The first hypothesis concluded that comparatively middle class families are more in favour of women's participation in productive activities outside the home.

2. The second hypothesis concluded that women's participation in decision making is directly related with their working status.

3. The third hypothesis concluded that educated women are more consulted about their marriage as compared to illiterate or less educated women.

4. The fourth hypothesis concluded that educated women, as compared, to illiterate or less educated women, believe in gender equality.

\section{Limitation of the Study}

The present research was limited to only small sample due to shortage of time and resources. The universe of the study was too large it was really a difficult task for researcher to interview all women living in Karachi, therefore, it was not practically possible for the researcher to cover all universe within available resources and time.

Second limitation of the present study was that the researcher had to probe into personal and private matters of the urban women, usually they do not like to answer such personal questions as about marriage, marital life, husband wife relationship, sexual harassment, husband wife communication about family planning, social mobility, decision making and discrimination against women from home to office. Usually these questions are treated against the family traditions and societal norms. In spite of socio psychological and cultural barriers the researchers tried their best to collect valid data as possible after establishing the best rapport with the subject.

\section{Recommendations}

There is wide scope of research on this particular topic. This study which was confined to only one city of Pakistan can be extended to other cities of Pakistan, for more accurate findings. The researcher is of the view that if this study of discrimination against women: a case study of urban women could be conducted on a large scale, the findings could be made more useful and more significant.

In the light of the findings of the present study, the researcher would like to make the following suggestions and recommendations for the welfare and progression of Pakistani women in general and especially educated, middle and lower middle class urban women.

Governmental and non-governmental institutions/agencies have to put in hard work to increase of gender equality, at the gross root level, because gender discrimination is one 
of the major problem of Pakistani women, and it is also a main hurdle in the way of over all socio-economic development of the country. Secondary education should be made be made compulsory and free for both boys and girls, informal education, semi-technical education and vocational training leading to employment and self-employment may also improve the socio-economic condition of Pakistani women, and can promote various aspects related to status and role of women in society, health issues, marriage, family, number of children, knowledge, opinion, and practice of family planning, housing condition and other economic issues.

Through informal education, and adult education community and religious leaders, parents, social workers and political leaders should be informed about the advantages of gender equality and women empowerment.

Pakistani women work hard and earn less and have no access to technology or training. They are not aware of their rights and privileges. Government should provide them facilities and opportunities for basic education, basic health and they need to be trained in income generating skills, child care, nutrition and family welfare education.

Mass media campaigns should be initiated by government and non-governmental organisations to raise self-image of women, and to raise awareness regarding women's contributions and importance of their role in national development. Focus should be on creating a favourable social milieu for and acceptance of women's participation in social and economic activities.

It is suggested that to end all discriminatory laws, clauses and practices against women and minorities and to promote progressive narrative and movements in Pakistan parallel to religious extremist ideologies that suppress women and girls. It is also recommended to make the National Commission on the Status of Women an autonomous body with its independent mandate, programs, policies and functions. It is further recommended to promote progressive legislation on ending discrimination against women and to implement all laws effectively through a coordinated response passed by the Government of Pakistan.

\section{References}

Bano,Sabra.(1997) "Women, Class, and Islam in Karachi," in Family and Gender in Pakistan:Domestic Organization in a Muslim Society, ed. Hastings Donnan \& Frits Selier, New Delhi: Hindustan Publishing Corporation, Pp 189-207.

Fawcett, J.T., Khoo, S. and Smith, C.P. Eds. (1984) Women in the Cities of Asia: Migration and Urban Adaptation. Boulder, Colorado: Westview Press. 
Freeman, Jo. Ed. (1995) Women: A Feminist Perspective. Michigan: Mayfield Publishing Company.

Hausmann, R., Tyson, L., and Zahidi, S. (2008) The Global Gender Gap Report 2008. Geneva: World Economic Forum, 2008.

Henslin, J.M. (1992) Sociology of Marriage and Family: A Down-To- Earth Approach. Boston: Pearson.

Holmes, M.(2007) What is Gender? Sociological Approaches. London: Sage Publications.

Jaffri, S. M. (2004) The Other Half: Discrimination against Women. Karachi: Royal Book Company.

Perveen, Rakhshinda (1999).Men:Partners Not Masters:Towards Gender Equity in Family Planning in Pakistan, Royal Tropical Institue.

SDPI, (2008), Country Gender Profile, www.jica.go.jp/pakistan/english/office/others/pdf/ CGP_01.pdf

Sekaran,Uma.(1992).Research Methods for Business :A Sikill-Building Approach. New York: John Wiley and Sons.

Thio, A. (1996) Sociology (Fourth Edition).New York: Harper Collins.

World Conference on Human Rights. (1993) Vienna Declaration and Program of Action, part 1.Vienna: United Nations.14- 25 June 1993

Dr. Fateh Muhammad Burfat is Professor in the Department of Sociology, University of Karachi

Dr. Naima Saeed is Assistant Professor in the Department of Sociology, University of Karachi

Dr. Ghulam Muhammad Burfat is Assistant Professor in the Department of Sociology, University of Karachi 